\title{
ZARYA DIAMOND DEPOSIT, YAKUTIAN PROVINCE, RUSSIA
}

\author{
V.V. Polyanichko, R.F. Salikhov, V.P. Serov, F.F. Tyurin, K.V. Garanin, Z.V. Spetsyus, \\ O.V. Tarskikh, M.Yu. Zezekalo \\ PJSC ALROSA, GaraninKV@alrosa.ru
}

\section{Introduction}

Zarya pipe is located on the southeast flank of Alakit-Markhinskoe Kimberlite Field, DaldynoAlakitsky Diamondiferous, Yakutian Diamondiferous Province, Russia. The pipe is on the territory of activity Aikhal mining and concentration complex (MCC) of OJSC ALROSA, being located $2 \mathrm{~km}$ south-east of the Aikhal pipe and $3 \mathrm{~km}$ south-southeast of the mining and beneficiation plant (MBP) №8, which produced kimberlitic ores refining of Aikhal and Komsomolskaya pipes.

\section{The pipe structure}

Permian-Triassic age trap complex rocks (basalts) and Carboniferous age terrigenous layers, totally $103 \mathrm{~m}$ thickness, overlap Zarya pipe. The pipe was discovered in 1973, after exploration drilling $(500 \times 500 \mathrm{~m})$. Initially the pipe was explored by diamond small-diameter drilling boreholes $(160 \times 80$ and $80 \times 80 \mathrm{~m}$ ), at low depth $(50 \mathrm{~m})$. According to a non-representative sampling of core (core diameter $90 \mathrm{~mm}$, total weight of 4.5 tons, the weight of core samples averaged $93 \mathrm{~kg}$ ), poor diamond grade was identified $(0.09 \mathrm{ct} / \mathrm{t})$. At the same time, diamond grade reached $0.9 \mathrm{ct} / \mathrm{t}$ for individual samples, and $0.23 \mathrm{ct} / \mathrm{t}$ for individual boreholes, and high quality diamonds were recovered. Thus, there was the chance of detecting high diamond grade fascia within the pipe, which could be additional source of kimberlitic ore for the MBP № 8 .

In recent years, Zarya pipe was re-explored by complex of estimation and exploration works including vertical and directional large-diameter boreholes (net $80 \times 40$ and $40 \times 40 \mathrm{~m}$ ) with total depth $500 \mathrm{~m}$ (at absolute level $+100 \mathrm{~m}$ ). It was possible to increase the weight of the individual 10 -m core samples up to $260-450 \mathrm{~kg}$ for ordinary boreholes and $1000 \mathrm{~kg}$ for cluster boreholes. After last phase of exploration it was identified: the pipe size is $480 \times 260 \mathrm{~m}$, and the size of the central ore column is $350 \times(180-60) \mathrm{m}$. Industrial mining is proposed for is the central ore column formed by phase II kimberlite (autholitic kimberlites). The average content of diamonds is $0.25 \mathrm{ct} / \mathrm{t}$ (phase II autholitic kimberlites), while the flanks of the deposit (porphyry kimberlites phase I) have grade $0.10 \mathrm{ct} / \mathrm{t}$.

\section{Geology and mineral composition}

The geological structure, mineral composition, diamond features, permafrost-hydrogeological, geological and engineering characteristics of the pipes were studied. Two main kimberlite types compose the pipe: porphyry kimberlites (intrusion phase I) and autolithic kimberlite (intrusion phase II), sharply differing in the diamond grade and heavy fraction content. Autolithic kimberlite forms the central ore column, but porphyry kimberlites perform flanks of the pipe.

Porphyry kimberlites (PK) with low-grade of diamonds form North-West, South-East and South-West flanks of the pipe. These kimberlites are gray, light-gray, sometimes with insignificant shades: pale bluish or reddish-brown. The structure is mostly fine- and medium-porphyry, the texture is massive. Olivine excretions are completely serpentinized, their content varies from 13.54 to $30.52 \%, 22.99 \%$ average. There are low content of xenogeneic clasts represented by single fragments of sedimentary (on average $3.64 \%$ ) and mantle rocks $(0.25 \%)$. The average content of xenoliths of metamorphic rocks in porphyry kimberlites is $0.93 \%$. 
Autolithic kimberlites (AK) are gray rocks with a content of $9.55 \%$ xenoliths of sedimentary rocks. The texture of the rock as a whole is brecciated, and the kimberlitic groundmass is fine-mediumporphyry. The spherical texture of the kimberlite is clearly defined. The spherotoxic (spherical) zone is located along the periphery of the pseudomorphs and xenoliths of the sedimentary rocks in the form of small spherical separations of the micrograined structure and variable thickness. The zone is darker than the kimberlite at whole and includes pseudomorphs of olivine. The pseudomorph of olivine in the breccia is less in comparison with the porphyry kimberlite (19.31\% average).

The groundmass of kimberlites have serpentine-calcite composition.

There are not statistically significant differences of the contents of main rock-forming oxides in PK and AK. The kimberlites of both phases belong to moderate-titanium $\left(\mathrm{TiO}_{2}=1,5-1.55 \mathrm{wt} . \%\right)$ and moderate-magnesium ( $\mathrm{PC}-26.4$ wt. $\%, \mathrm{AK}-21.8$ wt. $\%$ ) rocks. The content of $\mathrm{CaO}$ varies in samples from 5.28 to $26.78 \mathrm{wt} . \%$, depend on varying grade of rocks carbonatization.

The average weight of the heavy minerals fraction is: $\mathrm{PK}-52.17 \mathrm{~kg} / \mathrm{t}(16.58-101.80 \mathrm{~kg} / \mathrm{t}), \mathrm{AK}-$ $59.02 \mathrm{~kg} / \mathrm{t}(3,80-307,40 \mathrm{~kg} / \mathrm{t})$. Variations in the contents of the heavy fraction depend on secondary magnetite. Content of such magnetite in some samples reaches to $83.4 \%$ of the total weight of the heavy fraction. Generally, the content of heavy fraction minerals in AK is more above $13 \%$ than in PK. A characteristic feature of indicator minerals in both rock types is sharp prevalence of picroilmenite (average content $2.76 \mathrm{~kg} / \mathrm{t})$ on pyrope $(0.43 \mathrm{~kg} / \mathrm{t})$. There is the almost complete absence of unaltered olivine, an isolated finds of diopside and chrome spinel in both PK and AK.

Garnets mostly presented by widespread raspberry-colored grains, with lower content of orange, orange-red, purple, red and pink grains. The frequency of garnets occurrence with relics of the reaction rims is $50.4 \%$. PK garnets are some larger in size than AK garnets and characterized by high thickness of kelyphitic reaction rims. Orange grains are dominated among PK garnets (69\%), while such garnets are not widely presented in AK (29\%). Raspberry varieties of garnets are more dominated in AK (47\%), than in PK (23\%). In our opinion, for this reason, the AK diamond grade is several times above, than in the PK.

Lherzolite paragenesis garnets are dominated $(69,2 \%)$. There are mostly low- $\left(0.2-2 \mathrm{wt} . \% \mathrm{Cr}_{2} \mathrm{O}_{3}\right)-$ $23 \%$, and moderate-chromium garnets $(2-4 \mathrm{wt} . \%)-24.3 \%$, with lower amounts of medium- (4-8\%) $14.1 \%$, and high chromium (>8 wt. $\%)-7.6 \%$ ) grains. Dunite-harzburgite paragenesis garnets present $10,97 \%$ of the total number studied, where diamond association diamonds of dunite-harzburgite paragenesis are $7.74 \%$, and presented by low-calcium chromium pyropes. Low-calcium chromium pyropes of the Zarya pipes are characterized by higher contents of titanium, chromium, relatively lower contents of iron and calcium compare with similar garnets from ultra-high and high diamondiferous kimberlites of Yakutian Diamondiferous Province.

Eclogitic paragenesis garnets (17.42\% of total) presented by: the magnesian almandine $(16.12 \%)$, calcic pyrope-almandines $(0.65 \%)$ and titanium pyropes $(0.65 \%)$. A number of diamond association garnet of the eclogite paragenesis is $1.29 \%$, where garnets presented by calcic pyrope-almandines and titanium pyropes.

Werlitic garnets are most rarely presented $-1.94 \%$. There are titanium pyropes, chromium pyropes and uvarovite-pyropes.

Ilmenites of the Zarya pipe characterized by the widest presence of grains with reaction rims compare with ilmenites from other kimberlites of the Yakutian diamondiferous province. Rim zones are characterized by different thickness and mineral composition. Microprobe analysis established that ilmenite presented by picroilmenite ( $\mathrm{MgO}$ 7.85-of 12.52 wt.\%), with wide variations of $\mathrm{Cr}_{2} \mathrm{O}_{3}$ contents $(0.19-5.05 \mathrm{wt} . \%)$. 
Diamond crystals in Zarya pipe presented by types I, IV, VIII according to the Yu.L. Orlov classification. There are mostly type-I diamonds, a single discovery of coated cube (type-IV) and low proportion of polycrystalline intergrowths (type-VIII). Type-I diamonds presented by octahedrons (15.7\%), laminar rhombic-dodecahedrons $(22.8 \%)$, crystals of the transition habitus $(14.1 \%)$ and typical rounded diamonds (18.2\%). The type-VIII diamonds are presented by gray and black polycrystalline aggregates of octahedrons or transitional forms, with numerous inclusions of graphite and and various photoluminescence. Crystals with evidence of natural etching are widely presented $(41.2 \%)$. Such diamonds represented mostly by the crystals with etching channels, "scars", the triangular hollows and plastic deformation bands. The total content of diamonds with ultramafic assemble inclusions is 2.4, while the share of diamonds with eclogite assemble inclusions (omphacite and orange garnet) is only $0.2 \%$. This, along with the features of garnet, ilmenite and pyroxene, indicates the predominance of ultrabasic rocks on eclogitic in the upper mantle under the pipe.

The majority of the diamonds $(82.5 \%)$ characterized by medium transparency, with lower quantity of diamonds $(6.6 \%)$ with high transparency. Colored diamonds share is $34.0 \%$. Different shades of brown diamonds $(22,2 \%)$ and grey crystals $(10.0 \%)$ dominate among the colored diamonds. There is also low quantity of "sea wave" color diamonds.

The quantities diamonds with the blue and pink-lilac photoluminescence are the same ( $35 \%$ for each variety). There are lower contents of diamonds with yellow-green, yellow, orange (totally 17.8\%) photoluminescence. Generally, Zarya pipe diamonds presented by low-nitrogen varieties.

\section{Resources and development}

Total resources of the deposit are following: ore $-39.7 \mathrm{mln} \mathrm{t}$, diamond $-7.1 \mathrm{mln} \mathrm{ct}$, where ore reserves of the central ore column: ore $-20.8 \mathrm{mln} \mathrm{t}$, diamonds $-5.25 \mathrm{mln}$ ct. Economical mining is effective to the absolute level $+300 \mathrm{~m}$, with diamonds cut-off grade 0.221 (sive size $+0.5 \mathrm{~mm}$ ) according to the Prefeasibility Study.

In June 2016 quarry construction was started in Zarya mine. In 2019 initial bulk sample (100,000 t) is planned. Pilot mining will provide technological characteristics of ores, recovery of 2,000-2,500 carats of diamonds, estimation of diamond quality, carat price, and the profitability of the overall Project. 